\title{
Conceptual Model of Essential Oil Agroindustry Development by Using System Dynamics Approach
}

\author{
Ernaning Widiaswanti ${ }^{*}$, Rika Yunitarini \\ Department of Industrial Engineering, Faculty of Engineering, Trunojoyo University, Bangkalan, Indonesia
}

\begin{abstract}
Essential oil industry is a growing industry in Indonesia due to the abundance of raw materials. However, the current production rate is still not able to meet the demands of domestic and foreign industries. This research aims to map Indonesian essential oil agroindustry, which starts from the supply of raw materials at the farm level to the marketing of products of essential oils at the exporter level. This research employed system dynamics approach. A conceptual model was built to determine factors that influenced the production of essential oils along the supply chain and is presented in a causal loop diagram. The results of this research indicate that the price factor is the main factor influencing the production of essential oils, and can be used as a basis to assist in determining the strategy for developing essential oil agroindustry in the future. This research will be useful for policy makers, all business actors involved in the essential oil agroindustry, and future researchers.
\end{abstract}

Keywords: Essential oil agroindustry, Causal loop diagram, System dynamic

\section{Introduction}

In terms of the availability of raw materials, labor, and market opportunities, essential oil is one of the agroindustry products that has the potential to be developed ${ }^{[1]}$. Essential oil is a type of oil that is distilled from various kinds of plants, such as lemongrass, vetiver, clove, cananga or ylang-ylang, cinnamon, patchouli, rose, and others. Essential oils are obtained from roots, stems, flowers, and leaves of plants that have been extracted beforehand ${ }^{[2,3]}$. Essential oils are now increasingly becoming a concern because they are relatively safe, have many benefits, and are widely accepted by consumers. The benefits and natural activities of essential oils are related to their chemical content. The chemical component of essential oils determines their commercial values as raw material for industry. Essential oils are used as raw materials or indirect materials in the manufacture of fragrances and flavors. There are a lot of industries that utilize essential oils, including cosmetic industry, chemical industry, pharmaceutical industry, and food industry ${ }^{[4-7]}$.

No less than 40 types of essential oils that have been recorded and have been traded on the global market can be produced in Indonesia ${ }^{[1]}$. Of these 40 types, 13 types, which are patchouli, lemongrass, cloves, ginger, nutmeg, pepper, cinnamon, sandalwood, jasmine, vetiver, ylang-ylang or cananga, eucalyptus, and cubeb, have expanded to the global essential oil market ${ }^{[8,9]}$. Data from Statistics Indonesia, which was processed by the Ministry of Trade, have shown that the value of Indonesia's essential oil exports has increased from year to year (Fig. 1). The main export destination countries for Indonesian essential oils are (1) the United States, which covers $26.30 \%$ of all exports of Indonesian essential oils to the global market, (2) Singapore with a market share of $17.24 \%$, (3) France with a market share of $10.37 \%$, (4) India with a market share of $9.51 \%$, and (5) Switzerland with a market share of $6.98 \%$.

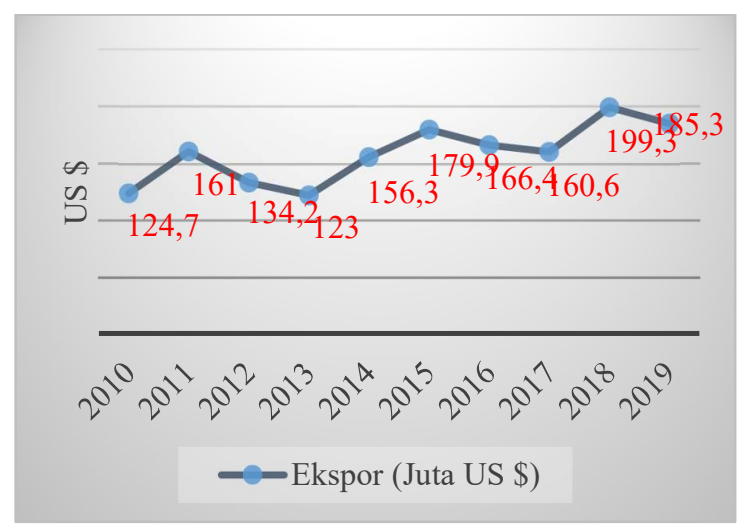

Fig. 1. The Export Value of Indonesian Essential Oil from 2010-2019

The data above show that the potential of natural resources is high and market opportunity for Indonesian essential oil agroindustry is big. The opportunity is even bigger due to the development of industry that utilizes essential oils, increasing population, and awareness to use natural essential oils because it is safer than synthetic chemicals ${ }^{[10]}$. The development of essential oil

* Corresponding author: erna.widiaswanti@gmail.com 
agroindustry will have an important impact because it may expand employment opportunities, increase added value, and build an economy that has a comparative advantage.

Meanwhile, Indonesia faces competition with other exporting countries, such as China, India and Brazil ${ }^{[11]}$. The tight competition in the global market and the increasingly demanding market requirements in developed countries requires the Indonesian essential oil industry to be able to increase the productivity, efficiency, and quality of their products ${ }^{[12]}$. Therefore, effective and efficient development strategies are needed to improve the competitiveness of the essential oil agroindustry.

Solutions and strategies for developing essential oil agroindustry need to be formulated. Development strategy formulation starts with an analysis of the current condition of the essential oil agroindustry. Analysis of current conditions is illustrated by a conceptual model of system dynamics approach. In the case of Indonesian essential oil agroindustry, there is a tendency for situations that often change, for example, uncertain price change that affects the production of essential oil ${ }^{[12]}$. Prices are not the only cause of the decline in essential oil production. There are still other interrelated factors. Many variables that affect a variable make the system complex. Problems that are complex and variables that change over time can be solved using system dynamics. System dynamics are also used for simulations and predictions of objects ${ }^{[13-15]}$. Conceptual model using system dynamics approach will show the complexity and dynamics of factors that contribute to the Indonesian essential oil production.

Previous studies using system dynamics approach have been conducted. Yudi et al. (2016) developed system dynamics modelling to analyze management performance and the performance of cassava farmers. Rahmah et al. (2017) analyzed the maize production system in Indonesia by using system dynamics. The same analysis of different commodity, namely citrus, was conducted by Ferreira et al. (2016). Research that uses system dynamics is able to solve complex problems $[16,17]$.

From several previous studies that have been conducted, there has been no research on the development of the essential oil agroindustry by using system dynamics approach. The advantage of system dynamics is that the system is more informative in presenting forecasting data, more accurate in describing short and medium-term behaviors, and more in depth in the development of scenarios ${ }^{[18]}$. The purpose of this research is to map and illustrate the complexity of the Indonesian essential oil agroindustry, starting from the supply of raw materials at the farmer level to the marketing of essential oil products at the exporter level. Conceptual model is designed to provide easy understanding of the system as a whole, so that the linkages between factors can be understood clearly.

\section{Research Method}

This research was conducted using the system dynamics method. The essential oil product that was observed in this research was cananga oil. Cananga essential oil was chosen because Indonesia is known as one of the producers of cananga oil and cananga oil is a leading export product ${ }^{[1,19]}$. In the global market, cananga oil from Indonesia is known as Java Cananga Oil [20]. The research site was Blitar Regency, East Java, Indonesia. Blitar Regency was chosen as the research site because there are many cananga trees as raw material for essential oils and several distillation activities in the regency. Based on data that were obtained from East Java Province Regional Development Planning Agency in 2013, Blitar Regency accounted for approximately $80 \%$ of Indonesia's exports of cananga essential oil.

The stages of this research were:

1. Surveys and interviews with cananga essential oil agroindustry actors in Blitar Regency regarding existing problems, production processes, and business processes;

2. Literature research on the development of cananga essential oil agroindustry, system dynamics concept, and supply chain formation;

3. Forming supply chain of cananga essential oil agroindustry in Blitar Regency. The supply chain was designed based on interviews with cananga essential oil agroindustry actors;

4. Determining the factors that affect the production of cananga essential oil along the supply chain, starting from the level of farmer, producer, collector, and exporter;

5. Determining the relationship between factors, which were divided into four sub-models, namely, farmer, producer, collector, and exporter;

6. Forming a chain for each stage. Meanwhile, data were collected from:

1. Interviews of 4 cananga oil producers, 1 cananga oil collector, and 34 cananga farmers. The largest cananga production center is in Ponggok District, with a total area of 149.6 ha and an average production of 676.94 tons/year, while other production centers are also found in several other districts. Blitar Regency has 2 centers of essential oil distillation, which are in Ponggok District and Srengat District with 8 business units and 89 workers [21];

2. Data that were obtained from the Statistics Indonesia.

\section{Results}

\subsection{Problem Identification}

Cananga oil is an essential oil that has been traded and exported since the colonial era ${ }^{[1,22]}$. However, at present, the production of cananga essential oil continues to decline ${ }^{[1]}$. The global demand for cananga essential oil is around 120-130 tons per year ${ }^{[23]}$. Statistics has shown that annually, Indonesia is only able to export an average 
of 20 tons of cananga essential oil [24], of which approximately 16 tons are produced in Blitar District. At present, the production rate of cananga in Blitar has decreased, as shown in Fig. 2. This is due to the fact that many of the cananga plants were abandoned by farmers, they switched to planting other crops that could produce more profits. It has an impact on the decline in production of essential oil in Blitar Regency. The decline in the production of cananga essential oil in Blitar Regency will consequently have a direct effect on Indonesia's export values. Indonesia's position as a producer of cananga essential oil may be displaced. If these conditions continue to occur, of course it will be difficult for Indonesia to survive and compete as a major exporter of cananga essential oil.

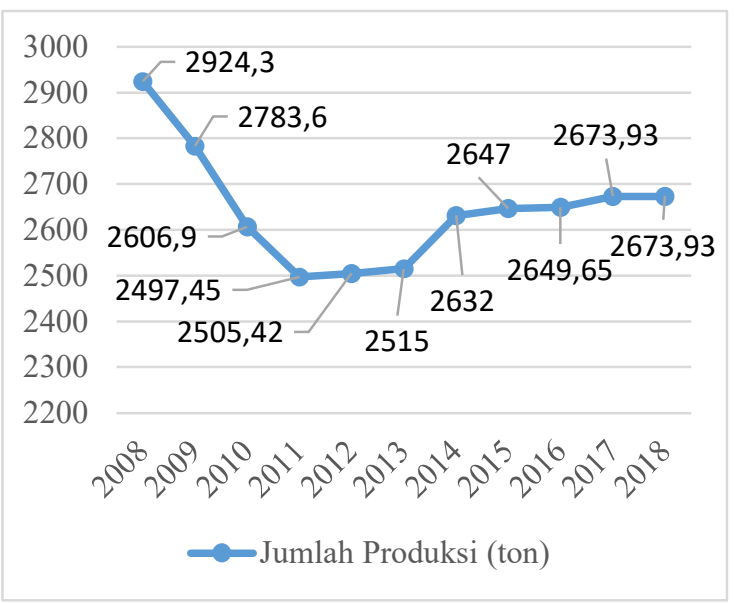

Fig. 2. Production Rate of Cananga

The decline in the production of cananga essential oil, presumably due to fluctuating prices. In the business process of cananga essential oil agroindustry network, prices are determined by market mechanisms ${ }^{[19]}$. This condition is certainly not very beneficial for all parties in the supply chain network of the essential oil industry. Producers bear the risk of uncertain income, and may even incur losses, while consumers, who are personal producers such as small-scale producers, bear the risk of uncertain production costs. Price uncertainty results in uncertainty of profit margin obtained by actors in the supply chain network.

Interviews were conducted with the business actors of cananga essential oil agroindustry in Blitar Regency. From the interview results, it can be concluded that:

1. The process of cananga essential oil production still employed a simple processing system.

2. There was no synergic cooperation of actors in the supply chain network of the cananga essential oil agroindustry with the local government and other business partners.

3. Quality standards required support from the government so that international market standards could be met properly. In addition, cananga essential oil agroindustry might have a bargaining position related to price and quality if producers knew the quality of the essential oils they produced.
4. Farmers switched to planting other commodities instead of cananga because other commodities generated profits faster, so the supply of raw materials for the distillation activities was reduced.

5. The prices of cananga and cananga oils tended to be unstable.

\subsection{Cananga Oil Supply Chain}

Cananga oil is derived from fresh cananga flowers that go through a process of distillation. Cananga that is considered as a native plant of Indonesia is Canangium odoratum Baill. forma macrophylla, while ylang-ylang (Canangium odoratum Baill. forma genuina) is cananga originating from the Philippines. Cananga and ylangylang belong to the family Annonaceae ${ }^{[25]}$. Cananga is also widely planted in Polynesia, Melanesia, and Micronesia ${ }^{[26]}$. Cananga essential oil products require many processes to reach consumers. There are many parties involved in the distribution of cananga essential oil products, ranging from farmers to exporters. Fig. 3 shows the supply chain and actors in the cananga essential oil agroindustry.
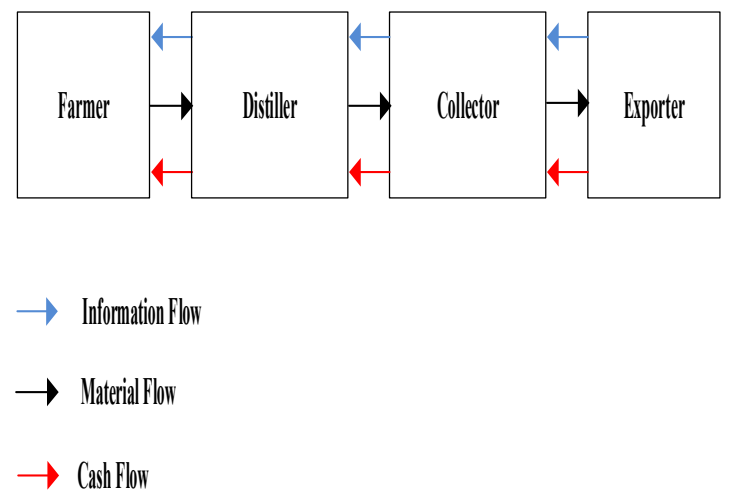

\section{Fig. 3. Supply Chain of Cananga Essential Oil}

Farmers plant cananga and they obtain cananga seedlings by plant cuttings. The new plants from cuttings can be planted in other media and then transplanted. They can also be planted directly in the land that has been prepared. Cananga can be harvested in 4-5 years. Cananga has varied growing season, depending on the area where it grows. Cananga flower harvest volume depends on plant age and season conditions. The older the age of the plant is, the higher the harvest volume becomes ${ }^{[26]}$. Cananga flowers that have been harvested are sold to producers who own distilleries.

The distillation process that was applied in Blitar Regency was water distillation. This process is most widely used by essential oil farmers in Indonesia [27]. Cananga oil quality is strongly influenced by differences in the growth area of cananga, hervest timing, and flower maturity ${ }^{[28]}$. Distillers sold cananga oil directly to collectors. Collectors were from Jakarta and usually came directly to the distilleries. Collectors sell cananga essential oils to exporters. Exporters will export cananga essential oils abroad. Most of the cananga essential oils 
are sold to European countries (France, Britain, Germany), the United States, Japan, and Singapore.

\subsection{Conceptual Model}

The conceptual model will be developed by taking into account the components that influence the production rate of cananga essential oil in the cananga essential oil agroindustry.

\subsubsection{Chain at the Farmer Level}

Cananga harvest volume is determined by many factors, including planting area, harvesting area, productivity, and land-use change. Land-use change from land for cananga plants to more productive plants in Blitar Regency is around $15 \%$ per year, causing a reduction in the area of cananga plantations ${ }^{[29]}$. As a consequence, it greatly affected the production rate of cananga flower. The availability of cananga flowers in cananga farmers was greatly influenced by seasonal changes. During the rainy season, a 4- to 5-year-old cananga tree produced $1-2 \mathrm{~kg}$ of cananga flowers, while during the dry season, it produced $6 \mathrm{~kg}$ of cananga flowers. Government regulations related to the program to increase agricultural/plantation production of cananga plants in 2014 affected the harvest volume of cananga in Blitar Regency. The government provided 5,000 cananga seedlings and 5,000 $\mathrm{kg}$ of compost. The program had an impact on reducing the production costs incurred by cananga farmers.

In general, each factor gave a positive relationship to the total harvest volume of cananga, meaning that if there was an increase in the factors, except for the factor of land-use change, the total harvest volume of cananga would also increase. If many farmers replaced cananga plants with other plants that were more financially profitable, then the harvest volume of cananga would decrease. The relationship between factors can be seen in Figure 4.

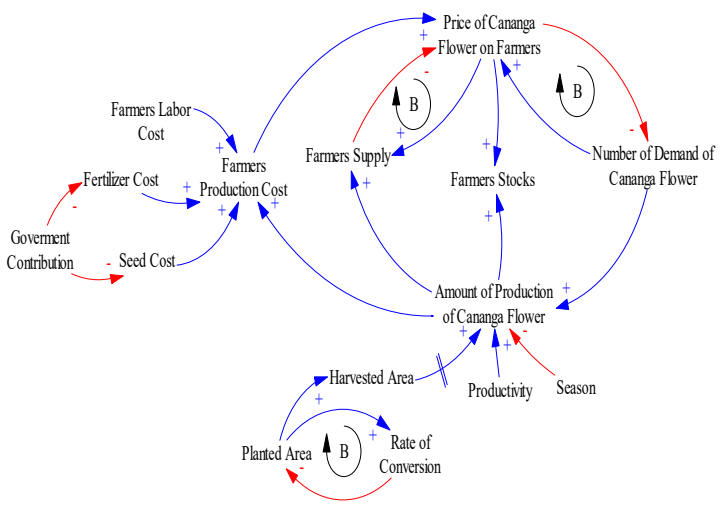

Fig. 4. Chain at the Farmer Level

\subsubsection{Chain at the Distiller Level}

Cananga oil production is influenced by several factors, which are supply of raw materials from farmers, distillery capacity, processing technology, and yield of oil produced. Supply of fresh cananga flower from farmers greatly influences the production rate of cananga oil production. In certain months, producers do not obtain supply of flowers from farmers because farmers prefer to sell their products directly to local market to meet the demand of the wider community. The community usually uses cananga flowers in ritual and cultural activities. Cananga flowers are used during wedding ceremonies and grave visits ${ }^{[26]}$. In these months, producers inevitably have to stop production.

The number of distillers in Blitar Regency was currently 8 distillers ${ }^{[21]}$. Each distiller had an average of 5 boilers with a production capacity varying between $500-1,000 \mathrm{~kg}$. Distillation was conducted for an average of 62 hours by the water distillation ${ }^{[27]}$. Yield of cananga oil was strongly influenced by the length of storage period of flowers before distillation ${ }^{[30]}$, the prevalence of contaminants, and machine efficiency. Distillers received many cananga flowers whose quality was below the standard and it resulted in low yields of cananga oil. Another factor that caused the low yield of cananga oil was the boilers of the producers that alredy passed through generations, so the machine efficiencies were low. Each distillation process required 4-5 workers per production. The distillation process was over wood fires using corn cobs, peanut shells, and husks ${ }^{[26]}$. In general, each factor gave a positive relationship to cananga production, meaning that if there was an increase in the factors, except the factors of length of storage period of flowers and prevalence of contaminants, the total cananga oil production would increase. The length of storage period of cananga flowers before the distillation process greatly affected the quality of cananga oil production. The prevalence of contaminants also affected cananga oil production. The more contaminants were found in raw materials, the lower the quality of production became. The relationship between factors can be seen in Fig. 5 .

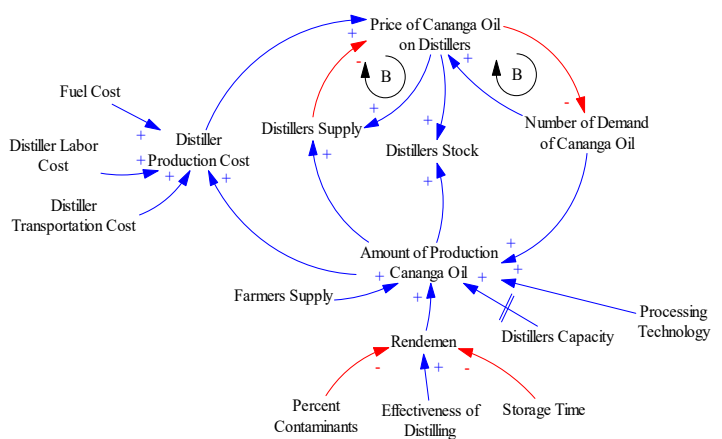

Fig. 5. Chain at the Distiller Level 


\subsubsection{Chain at the Collector Level}

The stock of cananga oil at collector level was influenced by various factors, such as the stock of cananga at distilleries, exporters demand, and prices at collector level, all of which had a positive relationship. Fig. 6 explains the relationship between these factors. Stocks of cananga oil from distillers greatly affected the availability of cananga oil at collector level. If cananga stock quantities at distiller level increased, cananga oil stock quantities at collector level would automatically increase. Collectors from Jakarta directly visited distilleries to do transactions ${ }^{[26]}$. Labor costs and transportation costs incurred by collectors had a negative effect on cananga oil stock at collector level. Transportation costs had a negative relationship with cananga oil at collector level because if transportation costs were high, the frequency of shipping was low.

The price of cananga oil was influenced by its quality, one of which can be seen from the ester number. Ester number is defined as the amount of organic acids that form compound of ester ${ }^{[31]}$. Increasing the ester number will increase the selling price of cananga oil. The current price of cananga is around IDR $1,350,000$ per kilogram.

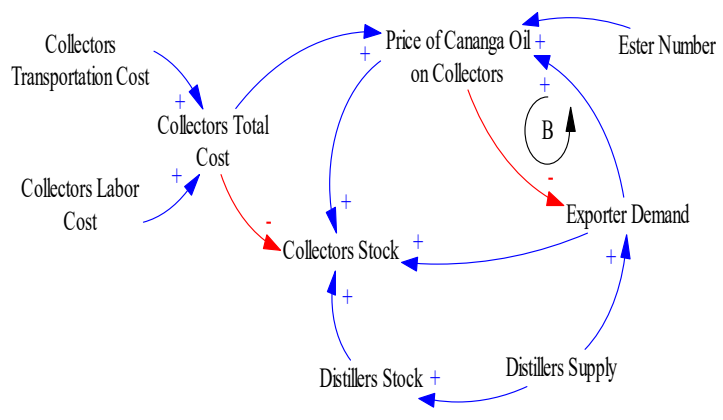

Fig. 6. Chain at the Collector Level

\subsubsection{Chain at the Exporter Level}

Cananga oil stock quantities at exporter level were influenced by four factors, namely, current price of cananga oil at exporter level, cananga stock quantities at distiller level, cananga stock quantities at collector level, and total costs incurred by exporters. The existence of collectors greatly affected cananga oil stock quantities at the exporter level. If the supply of cananga oil from collectors was increasing, the stock quantities in exporters would also increase.

In the supply chain of cananga essential oil agroindustry, prices are determined by market mechanisms. Price fluctuations mainly occured because of market price uncertainty. The price of cananga oil at the exporter level was influenced by prices in the global market. It indicated that if the price of cananga essential oil in the global market was high, then the price at the exporter would be also high.

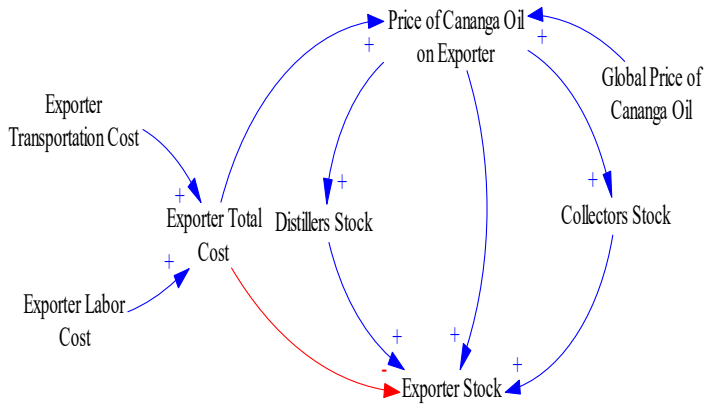

Fig. 7. Chain at the Exporter Level

\section{Discussion}

From the field research that had been conducted on the agroindustry of cananga essential oil, it was found that in general, the main problems in the Indonesian essential oil agroindustry was fluctuating prices. Business actors involved in the supply chain of the essential oil agroindustry consisted of farmers, distillers, essential oil collectors, and exporters. From the conceptual model that was built, it can be seen that price was a factor that affected the stock quantities at all four levels of the model. If the price increased, the stock quantities tended to increase, and vice versa. The stock of essential oils was affected by production rate. It indicated that price uncertainty resulted in uncertainty of the production rate of essential oil. Fluctuating prices of essential oil are determined based on international market mechanisms. This was in line with the results of interviews conducted with business actors in essential oil agroindustry and research conducted by Alighiri et al. (2017) and Hendrastuti et al. (2012), which stated that price fluctuations occurred due to uncertainty in market prices, product quality, and production rate of essential oil.

The role of government is needed in the development of essential oil agroindustry. Government policies must be emphasized to improve essential oil quality and stabilize essential oil prices. Stable prices are expected to increase the interest of business actors in producing essential oils. Policies that are made as a form of strategy to develop essential oil agroindustry must be able to address all problems and reach all aspects of agroindustry actors. Aspects that need government attention include: (a) aspects of the production process, which are related to the need to improve technology in the distillation process so as to improve the quality of essential oils, (b) marketing aspects, which are related to the need to strengthen competitiveness and develop downstream industry, (c) institutional aspects, which are public policies that are needed to support regulations to strengthen essential oil business chain, and (d) aspects of national character building, which are also needed to strengthen human resources for building entrepreneurial and competitive character. The government, in making policies, must consider all these aspects and the complex systems and thus, a thorough understanding of the system is needed. 
From the conceptual model that had been designed, it can be seen that the essential oils produced by producers could all be accommodated and bought by collectors and exporters, meaning that the essential oil products they produced were accepted by the market. This is a strength owned by Indonesian essential oil agroindustry where business opportunities are high because of high demand in the international market.

\section{Conclusion}

The main problems in the development of Indonesian essential oil agroindustry was price fluctuations. The purpose of using the system dynamic method was to map and illustrate the complexities of the Indonesian essential oil agroindustry, starting from the supply of raw materials to the marketing of products. The conceptual model was built to integrate the factors that influenced the production of essential oils in order to develop Indonesian essential oil agroindustry. From the conceptual model of the system dynamics that was created, it was known that the production rate of essential oil was influenced by price. If the price of essential oils was high, then the preference of farmers to plant essential oil-bearing plants would high, the frequency of distillation would increase, and the essential oil production would increase as well. The current price of essential oils was also thought to be a major factor in the declining production of Indonesian essential oils.

The conceptual model is a qualitative phase of system dynamics. Researchers in Indonesia and other developing countries can use this conceptual model to conduct quantitative testing in order to develop essential oil agroindustry. In addition, this conceptual model can be used as a consideration for policy makers in developing Indonesian essential oil agroindustry.

\section{References}

[1] Alighiri D, Eden WT, Supardi KI, Masturi, Purwinarko A. Potential Development Essential Oil Production of Central Java, Indonesia. J Phys: Conf Ser. 824(1): 1-5 (2017)

[2] Kusuma H, Mahfud M. Microwave Hydrodistillation for Extraction of Essential Oil from Pogostemon Cablin Benth: Analysis and Modelling of Extraction Kinetics. Journal of Applied Research on Medicinal and Aromatic Plants. 4: 46-54 (2017)

[3] Said Z, Haddadi-Guemghar H, BoulekbacheMakhlouf L, et al. Essential Oils Composition, Antibacterial and Antioxidant Activities of Hydrodistillated Extract of Eucalyptus Globulus Fruits. Industrial Crops and Products. 89: 167175 (2016)

[4] Adrar N, Oukil N, Bedjou F. Antioxidant and Antibacterial Activities of Thymus Numidicus and Salvia Officinalis Essential Oils Alone or in Combination. Industrial Crops and Products. 88: 112-119 (2016)
[5] Fernandes R, Botrel D, Silva EK, et al. Cashew Gum and Inulin: New Alternative for Ginger Essential Oil Microencapsulation. Carbohydrate Polymers. 153: 133-142 (2016)

[6] Ortiz de Elguea-Culebras G, Sánchez-Vioque R, Santana-Méridas O, Herraiz-Peñalver D, Delgado M, Berruga I. In Vitro Antifungal Activity of Residues from Essential Oil Industry Against Penicillium Verrucosum, a Common Contaminant of Ripening Cheeses. LWT - Food Science and Technology. 73: 226-232 (2016)

[7] Zlotek U, Michalak-Majewska M, Szymanowska U. Effect of Jasmonic Acid Elicitation on the Yield, Chemical Composition, and Antioxidant and Anti-Inflammatory Properties of Essential Oil of Lettuce Leaf Basil (ocimum Basilicum L.). Food Chem. 213: 1-7 (2016)

[8] Efendi E, Fauzi AM, Machfud M, Sukardi S. Rancang Bangun Sistem Peningkatan Kinerja Rantai Pasok Industri Minyak Atsiri. Journal of Technology Management. 13(2): 126-153 (2014)

[9] Gunawan W. Kualitas Dan Nilai Minyak Atsiri, Implikasi Pada Pengembangan Turunannya. In: Kimia Bervisi SETS (Science, Environment, Technology, Society) Kontribusi Bagi Kemajuan Pendidikan Dan Industri. Accessed June 22, 2020. https://docplayer.info/30038676-Kualitasdan-nilai-minyak-atsiri-implikasi-padapengembangan-turunannya.html (2009)

[10] Shaaban H, El-Ghorab A. Bioactivity of Essential Oils and Their Volatile Aroma Components: Review. Journal of Essential Oil Research. 24(2): 203-212 (2012)

[11] 11. Rosiana N, Feryanto F, Sinaga VR. Posisi Daya Saing Dan Tingkat Persaingan Minyak Atsiri Indonesia Di Pasar Global. Agricore: Jurnal Agribisnis dan Sosial Ekonomi Pertanian Unpad. 2(1): 216-220 (2017)

[12] $12 . \quad$ Hendrastuti H, Eriyatno E, Rusli MS, Soedarsono JW. Optimasi Penentuan Kesepakatan Harga Nilam Pada Rantai Pasok Minyak Atsiri Di Kabupaten Kuningan. AGROINTEK. 6(1): 16-21 (2012)

[13] 13. Jammernegg W, Reiner G. Performance Improvement of Supply Chain Processes by Coordinated Inventory and Capacity Management. International Journal of Production Economics. 108(1-2): 183-190 (2007)

[14] $14 . \quad$ Longo F, Mirabelli G. An Advanced Supply Chain Management Tool Based on Modeling and Simulation. Computers \& Industrial Engineering. 54(3): 570-588 (2008)

[15] 15. Sterman J. Business Dynamics: Systems Thinking and Modeling for a Complex World. Irwin/McGraw-Hill. (2000)

[16] 16. Chapman A, Darby S. Evaluating Sustainable Adaptation Strategies for Vulnerable Mega-Deltas Using System Dynamics Modelling: Rice Agriculture in the Mekong Delta's an Giang Province, Vietnam. Science of The Total Environment. 559: 326-338 (2016) 
[17] 17. Pan L, Liu P, Li Z. A System Dynamic Analysis of China's Oil Supply Chain: OverCapacity and Energy Security Issues. Applied Energy. 188(C): 508-520 (2017)

[18] 18. Lyneis JM. System Dynamics for Market Forecasting and Structural Analysis. System Dynamics Review. 16(1): 3-25 (2000)

[19] $19 . \quad$ Indonesian Essential Oils Council. Minyak Atsiri Indonesia. Published 2009. Accessed June 22, 2020. https://minyakatsiriindonesia.wordpress.com/20 09/06/10/minyak-atsiri-indonesia/

[20] 20. Pujiarti R, Widowati TB, Kasmudjo K, Sunarta S. Kualitas, Komposisi Kimia, dan Aktivitas Anti Oksidan Minyak Kenanga (Cananga odorata). Jurnal Ilmu Kehutanan. 9(1): 3-11 (2015)

[21] 21. Statistic of Blitar Regency. Blitar Regency in Figures 2018.; 2018. Accessed July 8 , (2020). https://blitarkab.bps.go.id/publication/2018/08/1 6/a505119e0104d78b8f567327/kabupatenblitar-dalam-angka-2018.html

[22] 22. Kuspradini H, Putri AS, Sukaton E, Mitsunaga T. Bioactivity of Essential Oils from Leaves of Dryobalanops Lanceolata, Cinnamomum Burmannii, Cananga Odorata and Scorodocarpus Borneensis. Agriculture and Agricultural Science Procedia. 9: 411-418 (2016)

[23] 23. Julianto TS. Minyak Atsiri Bunga Indonesia. Deepublish. (2016)

[24] 24. Fitri N, Mohammad D. Pengembangan Model Techno-Industrial Cluster Minyak Atsiri. AJIE. 4(3): 181-190 (2015)

[25] 25. Saedi N, Crawford GH. Botanical Briefs: Ylang-Ylang Oil--Extracts from the Tree Cananga Odorata. Cutis. 77(3): 149-150 (2006)

[26] 26. Widyastuti DE, Sukardi S, Ds VS, S $\mathrm{RD}$, Sulistyowati T. Enhance Industrial Competitiveness Through Improved Ylang Essential Oil Quality and Synergy Among Members of the Cluster. UNEJ e-Proceeding. 804-814 (2012)

[27] 27. Soedarwo VSD. Pengembangan Industri Non-Corporate Partisipatif Integratif Pada Industri Minyak Atsiri Kenanga. Jurnal Teknik Industri. 13(1): 31-36 (2012)

[28] 28. Rachmawati RC, Retnowati R, Juswono UP. Isolasi Minyak Atsiri Kenanga (cananga Odorata) Menggunakan Metode Distilasi Uap Termodifikasi. Jurnal Ilmu Kimia Universitas Brawijaya. 1(2): 276-282 (2013)

[29] 29. Statistic of Blitar Regency. Blitar Regency in Figures 2017. Published 2017. Accessed July $8,2020$. https://blitarkab.bps.go.id/publication/2017/08/1 6/29fe4c21452ac80d6b8db337/kabupatenblitar-dalam-angka-2017.html

[30] 30. Setyawan MA, Zakariyya M, Mahfud M. Pengambilan Minyak Atsiri dari Bunga
Kenanga Menggunakan Metode HydroDistillation dengan Pemanas Microwave. Jurnal Teknik ITS. 2(2): 282-285 (2013)

[31] Handayani R, Anggraeni SR, Gumilar I. Karakteristik Fisiko-Kimia Minyak Biji Bintaro (Cerbera manghas L) dan Potens inya sebagai Bahan Baku Pembuatan Biodiesel. Jurnal Akuatika. 6(2): 177-186 (2015) 